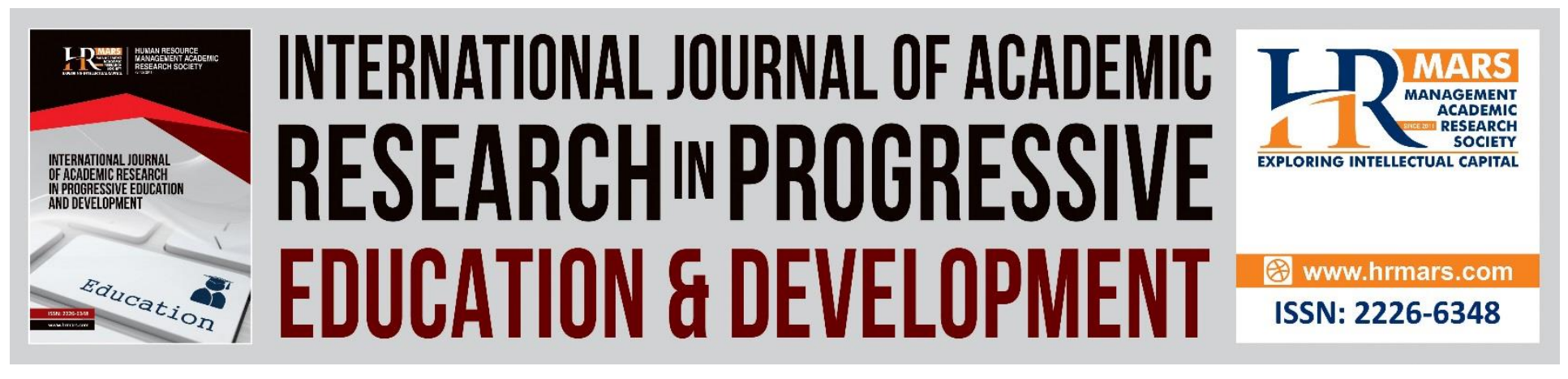

\title{
Word Blending using Sliding Word Lock to Enhance Reading Fluency
}

Fionee Anak Lawrence Loya, Hamidah Yamat

To Link this Article: http://dx.doi.org/10.6007/IJARPED/v10-i1/8878

DOI:10.6007/IJARPED/v10-i1/8878

Received: 13 December 2020, Revised: 20 January 2021, Accepted: 11 February 2021

Published Online: 27 February 2021

In-Text Citation: (Loya \& Yamat, 2021)

To Cite this Article: Loya, F. A. L., \& Yamat, H. (2021). Word Blending using Sliding Word Lock to Enhance Reading Fluency. International Journal of Academic Research in Progressive Education and Development, 10(1), 575585.

Copyright: (C) 2021 The Author(s)

Published by Human Resource Management Academic Research Society (www.hrmars.com)

This article is published under the Creative Commons Attribution (CC BY 4.0) license. Anyone may reproduce, distribute, translate and create derivative works of this article (for both commercial and non-commercial purposes), subject to full attribution to the original publication and authors. The full terms of this license may be seen at: http://creativecommons.org/licences/by/4.0/legalcode

Vol. 10(1) 2021, Pg. 575 - 585

http://hrmars.com/index.php/pages/detail/IJARPED

JOURNAL HOMEPAGE

Full Terms \& Conditions of access and use can be found at http://hrmars.com/index.php/pages/detail/publication-ethics 


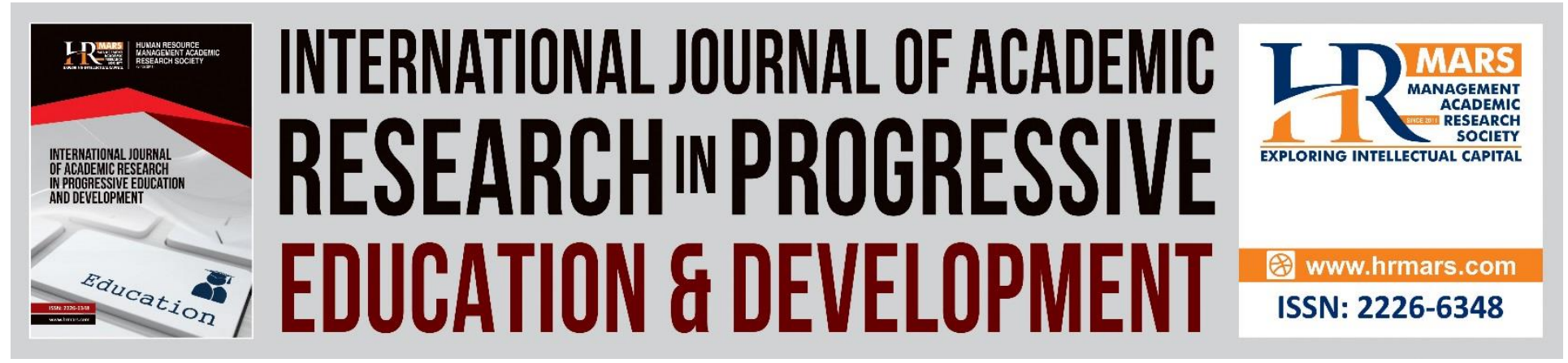

\title{
Word Blending using Sliding Word Lock to Enhance Reading Fluency
}

\author{
Fionee Anak Lawrence Loya \\ SK Long Busang, D/A Pejabat Pendidikan Daerah Belaga,96900 Belaga, Sarawak, Malaysia \\ Email: fioneelawrence1501@gmail.com
}

Hamidah Yamat

Faculty of Education, National University of Malaysia (UKM), 43600 Bangi, Selangor, Malaysia.

Email: hamidah_yamat@ukm.edu.my

\begin{abstract}
Having issues with synthetic phonics or word blending leads to inefficiency in reading fluently among rural primary school pupils causing the pupils to be demotivated in reading English books. Therefore, this quasi-experimental study was carried out to investigate the use of Sliding Word Lock which is incorporating the visual-kinaesthetic learning style to help in word blending enhancing reading fluency among rural primary school pupils. With 14 participants from rural primary school in Belaga, Sarawak, pre-test, post-test and one-minute timed reading passage assessment were used to collect the data required. The findings from pre-test, post-test and oneminute timed reading passage assessment were analysed using descriptive analysis. The pre-test and post test results reveal that all participants progressing positively in word blending through the pre-test and post-test. The result from one-minute timed reading passage assessment shows positive increasement in the number of words pronounced by the participants. This shows that Sliding Word Lock has a positive effect in word blending and it enhance the reading fluency of the participants.
\end{abstract}

Keywords: Word Blending, Reading Fluency, Cognitivism Theory, Multiple Intelligence Theory, Visual-kinaesthetic Learning Style

\section{Introduction}

Helfgott (1976) mentioned that most skills necessary for the initiation of reading acquisition are simple associative learning skill, such as recognizing and associating the alphabets with the sounds. In phonics, such skill is known as word blending. Universiti Malaysia Sarawak (UNIMAS) senior lecturer in Cognitive Science Program, Dr Julia Lee Ai Cheng (2019) said in the Star online that if the young children are not given the appropriate and systematic rigorous 
instruction in phonic awareness, phonics, fluency, vocabulary and reading comprehension strategies, they are at risk for reading failure upon entering kindergarten and primary school.

According to Kodan (2017) in Turkey, many students are having problems with reading fluently due to their poor preparation (poor readers) to join the class which causing them to fall behind their classmates and neglected. There is no exception to this matter including rural schools in Belaga, Sarawak as the pupils in the area are also having difficulties in mastering the word blending concept. This issue has leads to the incompetence in reading fluently.

Thus, this study aims to improve the teaching and learning of word blending to enhance reading fluency among Year 2 pupils through the implementation of Sliding Word Lock. It is an improvised technique used by the teacher in the class to help the pupils to master word blending skill. The purpose of the study is to explore the effectiveness of Sliding Word Lock in word blending towards enhancing reading fluency among rural primary school pupils.

\section{Research Objectives}

1. To determine pupils' number of word-blending before and after the use of Sliding Word Lock.

2. To determine pupils reading fluency before and after the use of Sliding Word Lock.

3.

\section{Research Questions}

1. What is the effect of using Sliding Word Lock to determine pupils' number of wordblending?

2. What is the effect of using Sliding Word Lock to determine pupils' reading fluency?

3.

\section{Literature Review}

Cognitivism Learning Theory

Cognitivism Learning theory pays attention to the internal process and connections which take place in learning. Leaners are active participants and information processor whose learning is defined through the change in their schemata. This involves the use of mental processes such as thinking, memory, knowing and problem solving. Cognitivism believes that learners employ various strategies to process and build understanding of the knowledge disseminated to them. The Sliding Word Lock functions to help the pupils to understand the idea of word blending and with the understanding of this theory, the pupils are expected to think, memorize, know the process of blending it and eventually able to pronounce the distinguishable word which will help them to read better.

Multiple Intelligence Theory

Another theory involved in this study is the multiple intelligences by Howard Gardner. This theory claims that everyone possesses different ways of learning and use different intelligences in their daily lives. Howard Gardner acknowledged seven types of intelligences which signify that everyone has different kind of minds and therefore they remember, learn, perform, and understand things in differing ways (Langworth and Gardner, 2010). In this study, the Sliding Word Lock aims to exercise the visual-kinaesthetic learning style. This is because, Sliding Word lock involves visual and body movement while learning word blending. Pupils are 
required to use their fingers to move the slide lock as they utter the phonemes pointed. This involves the pupils to exercise the mental processes of the brain which associated with thinking, knowing and remembering. At the same time, involving the fingers to slide the lock helps the pupils comprehend the concept of word blending. As the pupils / participants able to comprehend the concept of word blending, this will enable them to read fluently. Rasinski et al (2005) also stated that as the fluency in reading trades with the mastery of decoding effortlessly accurate.

\section{Reading Fluency}

The young learner learns to read through simple sentences with guidance from the teacher. In the study conducted by Schwanenflugel et al (2006), concluded that as the children utilize their word-reading ability to understand the gist of the text, the simple reading fluency model is applicable in the development of fluent reading in the early stage. As they grow older, the reader will be efficient in reading as they are able to read fluently and comprehend the text better. This is supported by Schwanenflugel et al (2006), mentioning that the challenges of the text required by the children will increases as the children gets older. National Reading Panel Report (2000) stated that evaluating fluency is essential because it provides a general point of view of the pupils' overall reading competencies. By evaluating reading fluency among primary school pupils, teachers get to discover which part or which aspect of reading that deter the pupils from reading fluently. This was supported by Palmer (2010), the discover found by the teacher through assessing fluency regular could help pupils in decoding, syllabication, or other word recognition issue. In this study, the word blending is the main issue that deter the pupils from reading fluently. Thus, Sliding Word Lock would be able to help in solving the word blending issue that faced by the participants.

\section{Methods}

The data collection procedures of this research study are as follows:

\section{Pre-test}

For the first step, the respondents were diagnosed using word blending test which is adapted from the English Reading Screening Test Instrument of LINUS 2.0 program to obtain their results on word blending. The One-minute timed reading of a passage assessment was conducted to obtain their result on reading fluency. The records of the result were themed as pre-test. 
INTERNATIONAL JOURNAL OF ACADEMIC RESEARCH IN PROGRESSIVE EDUCATION AND DEVELOPMENT

Vol. 10, No. 1, 2021, E-ISSN: 2226-6348 @ 2021 HRMARS

\section{Intervention}

Next, the second phase, the researcher who is also the teacher implemented the intervention which was using the Sliding Word Lock in treating the issues for 4 weeks. The respondents were exposed with the Sliding Word Lock and the colourful word cards to help the participants to blend the phonemes during the intervention.

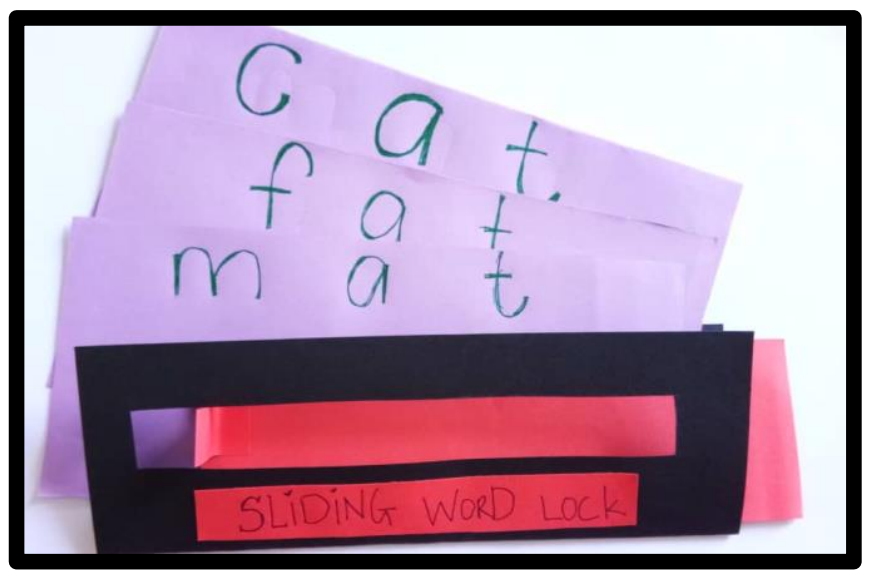

Figure 5.0 A set of the Sliding Word Lock and the (phoneme) word cards.

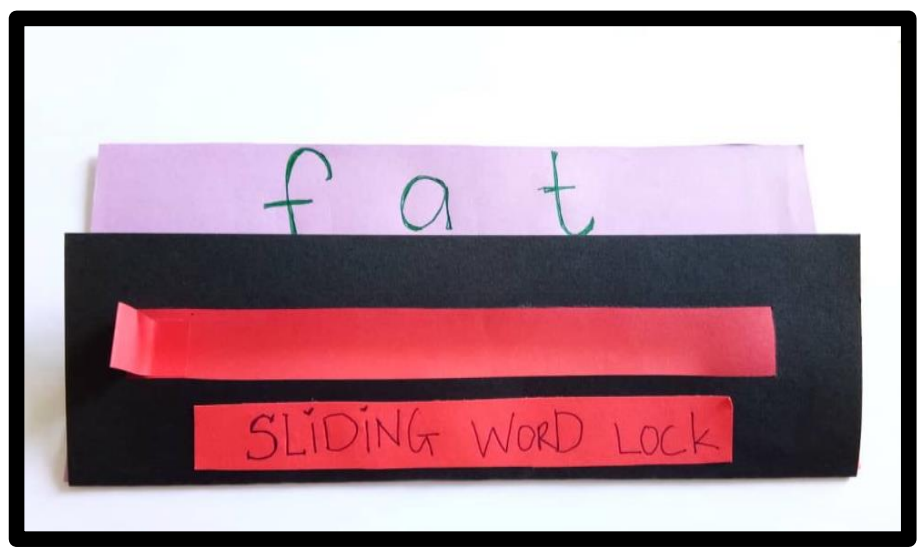

Figure 6.0 Sliding Word Lock functions like the sliding lock.

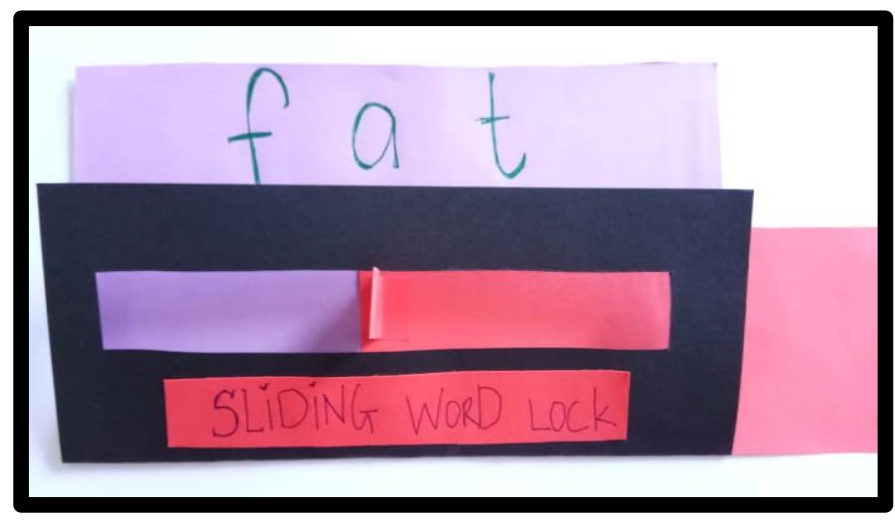

Figure 7.0 The Sliding Word Lock stopped at the phonemes which allowed the participants to produce the sound. 


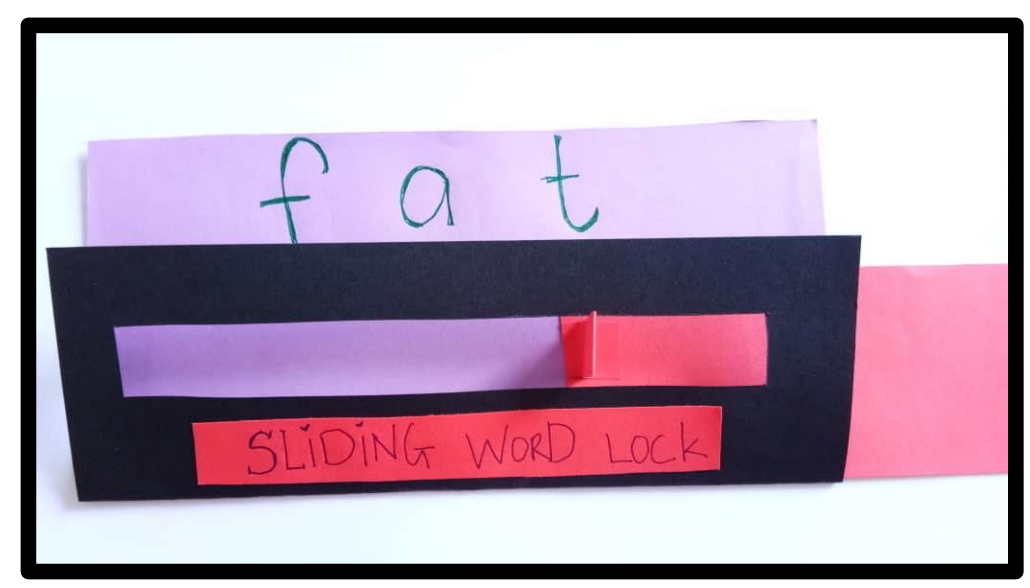

Figure 8.0 The sliding word lock stopped at the last phoneme which showed that the lock can be slide back to the first phoneme to help in blending the phonemes.

The Sliding Word Lock functioned like a sliding lock. The red lock as shown in figure 4.0 until figure 6.0 can move or slide from the first phoneme to another simultaneously as the participants produced the sound of the phonemes and blend the phonemes to produce a distinguishable word. At the early stage, the participant must slide the lock from one phoneme to another at a very slow pace because they are required blend the sound of the phoneme together. After many practices, the participant must slide the lock faster to help them to blend the phonemes better.

The lock can slide back to the first phoneme and repeat the whole process until the participants succeed in producing the correct distinguishable word. The idea of Sliding Word Lock is to illustrate the idea of blending the phonemes to produce distinguishable words in the participants' mind.

At the end of every week, as a remedial activity, respondents were given simple sentences to be read with guidance from the teacher. The reason was to exercise blending the words in the passage so that they can practice their reading fluency skill.

\section{Post-test}

After 4 weeks of intervention, the last phase was assessing respondent's mastery level using the same instruments used in the pre-test. This was to obtain their results on phonics literacy and the One-minute timed reading of a passage assessment was to obtain their result on reading fluency. The record of the results was themed as the post-test. With all the data collection methods mentioned, all the data obtained were examine appropriately. The findings were presented accordingly, and discussions were done based on the findings.

\section{Results / Findings}

The results of each data collection methods are as shown below: 
INTERNATIONAL JOURNAL OF ACADEMIC RESEARCH IN PROGRESSIVE EDUCATION AND DEVELOPMENT

Vol. 10, No. 1, 2021, E-ISSN: 2226-6348 @ 2021 HRMARS

\section{Pre-test and Post-test}

Pre-test and post-test were administered to the participants before the intervention and after the intervention. These tests were conducted to find out the difference between pupils' competency to blend phonemes into distinguishable words and the ability to part words into phonemes before and after the implementation of the Sliding Word Lock. The scores were recorded by the researcher and analysed using descriptive analysis through the calculation of percentage. The following table below is the findings:

\begin{tabular}{cccc}
\hline Participant & Pre - test (\%) & Post- test (\%) & Changes in percentage (\%) \\
\hline A & 40 & 90 & 50 \\
\hline B & 20 & 80 & 60 \\
\hline C & 20 & 80 & 60 \\
\hline E & 50 & 90 & 40 \\
\hline F & 20 & 80 & 60 \\
\hline G & 20 & 90 & 70 \\
\hline H & 40 & 90 & 50 \\
\hline I & 40 & 100 & 50 \\
\hline J & 60 & 100 & 30 \\
\hline L & 70 & 100 & 40 \\
\hline M & 60 & 100 & 60 \\
\hline N & 30 & 90 & 60 \\
\hline
\end{tabular}

Table 1.0 Participants' pre-test and post-test scores in percentage and the changes in percentages.

The pre-test and post-test results in table 1.0 revealed that all fourteen participants have shown there is a positive increasement in the number of words pronounced. This shows that the participants can blend phonemes into distinguishable words and part the words into phonemes after using the Sliding Word Lock to help them in the learning for a month. The results shows that the participants scored higher marks for their post-test, compared to their pre-test. Participant $F$ shows the highest change in percentage which indicate that participant $\mathrm{F}$ improves by $70 \%$ whereas participant J shows the lowest change in percentage which indicate that participant J improves by $30 \%$. The other 12 participants have shown changes ranging from $40 \%$ to $60 \%$. 
INTERNATIONAL JOURNAL OF ACADEMIC RESEARCH IN PROGRESSIVE EDUCATION AND DEVELOPMENT

Vol. 10, No. 1, 2021, E-ISSN: 2226-6348 @ 2021 HRMARS

\begin{tabular}{cccc}
\hline \multirow{2}{*}{ Participant } & \multicolumn{2}{c}{ CONCEPT 3 } & \multirow{2}{*}{ Changes in percentage (\%) } \\
\cline { 2 - 3 } & Pre- test (\%) & Post- test (\%) & \\
\hline A & 60 & 100 & 60 \\
\hline B & 20 & 80 & 60 \\
\hline C & 20 & 100 & 80 \\
\hline D & 60 & 100 & 40 \\
\hline E & 20 & 80 & 60 \\
\hline F & 20 & 100 & 80 \\
\hline G & 40 & 100 & 60 \\
\hline H & 40 & 100 & 60 \\
\hline J & 60 & 100 & 40 \\
\hline K & 80 & 100 & 20 \\
\hline L & 60 & 100 & 40 \\
\hline M & 40 & 100 & 60 \\
\hline N & 40 & 100 & 60 \\
\hline
\end{tabular}

Table 2.0 Participants' concept 3 pre-test and post-test scores in percentage and the changes in percentages.

Table 2 shows the findings of each of the pupils for concept 3 pre-test \& post-test. There are 5 items in construct 3 which measures the ability of the pupils to blend phonemes into distinguishable words. Results in Table 2 shows that the there are changes in pre-test percentage and post-test percentage. The changes in percentages shows that the score increases after the implementation of the Sliding Word Lock. There are 2 pupils manage to show $80 \%$ in advancement, 6 pupils show $60 \%$ in advancement, 5 pupils show $40 \%$ in advancement and only one pupil shows $20 \%$ in advancement. Even though that one pupil only shows $20 \%$ in advancement, she managed to obtain full marks in construct 3 as her pre-test was already the highest score. This shows that the Sliding Word Lock did impact the pupils to blend phonemes into distinguishable words better as there are 11 of the pupils manage to get full score in construct 3 whereas another 3 pupils manage to score $80 \%$ during their post-test. 
INTERNATIONAL JOURNAL OF ACADEMIC RESEARCH IN PROGRESSIVE EDUCATION AND DEVELOPMENT

Vol. 10, No. 1, 2021, E-ISSN: 2226-6348 @ 2021 HRMARS

\begin{tabular}{cccc}
\hline \multirow{2}{*}{ Participant } & \multicolumn{2}{c}{ CONCEPT 4 } & \multirow{2}{*}{ Changes in percentage (\%) } \\
\cline { 2 - 3 } & Pre- test (\%) & Post- test (\%) & 60 \\
\hline A & 20 & 80 & 60 \\
\hline B & 20 & 80 & 40 \\
\hline C & 20 & 60 & 40 \\
\hline D & 40 & 80 & 60 \\
\hline E & 20 & 80 & 60 \\
\hline F & 20 & 80 & 30 \\
\hline H & 40 & 80 & 60 \\
\hline I & 40 & 100 & 40 \\
\hline L & 60 & 100 & 40 \\
\hline K & 60 & 100 & 40 \\
\hline M & 60 & 100 & 60 \\
\hline N & 20 & 80 & 60 \\
\hline & 40 & 100 & 40 \\
\hline
\end{tabular}

Table 3.0 Participants' concept 4 pre-test and post-test scores in percentage and the changes

Table 3 shows the findings of each of the puppils fortagess items in construct 4 which measures the pupils' ability to part words into phonemes. Results in Table 3 shows that the there are changes in pre-test percentage and post-test percentage. The changes in percentages shows that the score increases after the implementation of the Sliding Word Lock. There are 7 pupils manage to show 60\% in advancement, 6 pupils show $40 \%$ in advancement, and only a pupil shows $30 \%$ in advancement. This shows that the Sliding Word Lock did impact the pupils to part words into phonemes better as there are 5 of the pupils manage to get full score in construct 4 whereas another 8 pupils manage to score $80 \%$ and a pupil manage to score $60 \%$ during their post-test.

\section{Discussion}

The differences between the pre-test and post-test reveal a positive impact produced by the participants after implementation of the intervention which is using the Sliding Word Lock in learning word blending. The results reveal that after a month of learning to blend the phonemes using Sliding Word Lock, the participants able to pronounce words correctly without hesitation and it has leads to reading fluently. Helfgott (1976) states that the children must understand the relationship between isolated phonemic sounds. Phonemic segmentation and blending skills are the skills that must be mastered by the pupils to help them in reading. This statement supports the findings as the participants able to blend the phonemes and produce distinguishable words. This shows that, the Sliding Word Lock is effective on the participants in learning word blending because they understood the concept of blending the phonemes.

From the results revealed in the One-minute reading a passage assessment, participants manage to prove that they able to improve on their reading fluency because of the improvements in the number of words pronounce in one minute after undergoing the word blending activity. This 
Vol. 10, No. 1, 2021, E-ISSN: 2226-6348 @ 2021 HRMARS

shows that the participants blend the phonemes faster and able to utter it correctly compared to the situation before the intervention.

\section{Implication}

This research study implies that the teacher needs to be creative and innovative to implement various kinds of teaching strategies to help the pupils to learn during lesson. As Gilakjani (2012) stated that teachers able to help pupils more effectively if we are aware of their learning style and able to help the pupils in determining the pupils' preferences. This strategy would work for the visual-kinesthetics learner as they could see and move the lock to help them blend the words. Especially, on the basic skill such as mastering phonics skills, the pupils of young age need the stimulus to be touchable and user friendly. Teacher also needs to help the pupils to grasp the concept of word blending creatively beside to attract their attention to learn this important skill and eventually master the word blending skill.

Other than that, this research study implies that as the pupils began to understand the concept of word blending, they can practice the skill on their own as they read the story books or other passages at the school library or at home with their parents. As they practice the word blending skill, this will help in their reading fluency. As their reading skill gets better, it helps in their motivation to read more books in the future.

\section{Conclusion}

To conclude, the process of word blending to enhance the reading fluency is not easy but never impossible for the primary school pupils. It can be achieved through appropriate strategy or creative intervention for instance the use of Sliding Word Lock. However, different background and ability of pupils serves different style of learning. Ergo, they may not be producing same result as the study. It is necessary for educators to experiment various types of strategies and techniques to be applied in their ESL classroom so that the pupils shall benefits from the desired learning objectives.

\section{Contribution}

In the critical reading perspective, according to Kodan (2017) stated that pupils that are having difficulties in reading fluently experiences concentration problem while reading. Therefore, this intervention that requires the pupils to master the word blending through Sliding Word Lock helps them to solve the difficulties in reading fluently. This is because as they able to master the word blending skill, they able to read any words and helps them to comprehend the text better. This supported by Kodan (2017) which states that in order reading comprehension to take place, it is important for the pupils to read fluently. Personally, in the context of the targeted school, this research has contributed to the increasing number of pupils able to pronounce English words correct and appropriately based on the result achieved. This has also enabled the teacher to exercise the method on other pupils who has the same issue in another class. Other than that, the teacher able to share the idea of the intervention with other teachers for them to adopt and adapt as needed to suit their own targeted pupils. 
INTERNATIONAL JOURNAL OF ACADEMIC RESEARCH IN PROGRESSIVE EDUCATION AND

DEVELOPMENT

Vol. 10, No. 1, 2021, E-ISSN: 2226-6348 @ 2021 HRMARS

\section{References}

Education, M. O. (2018). Kurikulum Standard Sekolah Rendah: Bahasa Inggeris Sekolah Kebangsaan - Dokumen Standard Kurikulum dan Pentaksiran. Putrajaya: Bahagian Pembangunan Kurikulum.

Gilakjani, A. (2012). Visual, Audiotory, Kinaesthetic Learning Style and their Impacts on English Language Teaching. Journal of Studies in Education, 104-113.

Helfgott, J. (1976). Phonemic Segmentation and Blending Skills of Kindergarten Children: Impliction for Beginning Reading Acquisition . Contemporary Educational Psychology Academic Press, 157-169.

Kodan, H. (2017). Determination of Reading Levels of Primary School Students. Universal Journal of Education Research, 1962-1969.

Langworth, R. M., \& Gardner, H. (2010). Multiple Intelligences. ReadHowYouWant.com, Limited. Retrieved from Read How You Want.

Malik, G. M., \& Alam, R. (2019). Comparative Analysis Between Pre-test / Post-test and Post-testonly Model in Achieving the Learning Outcomes. Pakistan journal of Ophthalmology, 408.

Ming, K., \& Dukes, C. (2008). Fluency: A necessary Ingredient in Comprehensive Reading instruction in Inclusive Classrooms. Teaching Exceptional Children Plus, 1-14.

Palmer, M. L. (2010). The Relationship between Reading Fluency, Writing Fluency, and Reading Comprehension in Suburban Third-Grade Students. ProQuest Digital Dissertation Database.

Rasinski, T. P. (2005). Is Reading Fluency a Key to Successful highschool reading? International Reading Association, 22-27.

Rasinski, T., \& Padak, N. (2005). One-Minute Reading Assessment. New York: Scholastic Inc.

Schwanenflugel, P. J. (2006). Becoming Fluent and Automatic Reader in the Early Elementary School Years. Reading Research Quarterly, 496-522.

Star, T. (2019). Education. Retrieved from Identifying Reading Problem Early: https://www.thestar.com.my/news/education/2019/11/24/identifying-readingproblems-early 